\title{
Artikel
}

\section{Kroniek jeugdstraf(proces)recht: the good, the bad \& the ugly}

Mr. drs. M. (Marije) Jeltes*

\section{NTS 2020/106}

\section{Inleiding}

In de periode 2019-2020 heeft het jeugdstraf(proces)recht een aantal veranderingen ondergaan. Ten eerste is Richtlijn 2016/800/EU van het Europees Parlement en de Raad van 11 mei 2016 betreffende procedurele waarborgen voor kinderen die verdachte of beklaagde zijn in een strafprocedure per 1 juni 2019 geimplementeerd in de Nederlandse wetgeving. Daarnaast heeft de Wet herziening tenuitvoerlegging strafrechtelijke beslissingen (Wet USB) tot het huidige Boek 6 van het Wetboek van Strafvordering (Sv) geleid. Hierdoor zijn onder meer bepalingen uit het Wetboek van Strafrecht die voorheen in de titel 'Bijzondere bepalingen voor jeugdigen en jongvolwassenen' stonden, verplaatst naar het Wetboek van Strafvordering. Niet alleen in het kader van wetgeving, maar ook in het kader van het beleid van het Ministerie van Justitie en Veiligheid heeft zich een aantal belangrijke wijzigingen voorgedaan, zoals het ontstaan van Kleinschalige Voorzieningen en de invoering van een landelijke pilot met betrekking tot de reprimande. Ook internationale ont-

Mr. drs. Marije Jeltes is docent en onderzoeker bij de afdeling Jeugdrecht van de faculteit der Rechtsgeleerdheid van de Universiteit Leiden. Daarvoor was zij 13 jaar werkzaam als (jeugd)strafrechtadvocaat. Zij is tevens (kinder)rechter-plaatsvervanger bij de rechtbank Amsterdam en rechtbank Rotterdam en lid van de afdeling Advisering van de Raad voor Strafrechtstoepassing en Jeugdbescherming (RSJ). wikkelingen zullen de revue passeren. Tevens zullen wetsvoorstellen met betrekking tot het jeugdstraf(proces)recht worden besproken, onder meer de voorstellen voor een nieuw Wetboek van Strafvordering. Er zal worden afgesloten met een beschouwing op alle ontwikkelingen, onder andere in het kader van het Internationale Verdrag inzake de Rechten van het Kind (IVRK), dat in de maand waarin deze editie het licht ziet, zijn eenendertigste verjaardag viert. ${ }^{1}$

\section{Implementatie Richtlijn 2016/800/EU²}

Het Europees Parlement en de Raad van Europa hebben in 2009 in het kader van een resolutie van het Europees Parlement en de Raad van Europa ter versterking van de procedurele rechten van verdachten of beklaagden in strafprocedures een routekaart uitgestippeld. ${ }^{3}$ Het Europees Parlement en de Raad hebben in het kader van die routekaart vier richtlijnen uitgevaardigd, die van

1. Gezien de maximale omvang van deze bijdrage is besloten een jurisprudentie-overzicht achterwege te laten.

2. Zie ook: M. Jeltes, 'Van Yusuf Salduz tot General Comment No. 24. Het recht op rechtsbijstand aan minderjarige verdachten in het Nederlandse jeugdstrafrecht in het licht van internationale kinderrechten', in: M.R. Bruning, K.F.M. Klep \& E.C.C. Punselie (red.), De invloed van 30 jaar Kinderrechtenverdrag in Nederland. Perspectieven voor de rechtspraktijk (Recht en Praktijk nr. PFR7), Deventer: Wolters Kluwer 2020, p. 127-141.

3. Zie toelichting in Richtlijn 2013/48/EU van het Europees Parlement en de Raad van 22 oktober 2013 betreffende het recht op toegang tot een advocaat in strafprocedures en in procedures ter uitvoering van een Europees aanhoudingsbevel en het recht om een derde op de hoogte te laten brengen vanaf de vrijheidsbeneming en om met derden en consulaire autoriteiten te communiceren tijdens de vrijheidsbeneming ( $P b E U \mathrm{~L}$ 294), preambule par. 9 
invloed zijn geweest op Nederlandse wetgeving betreffende de rechtspositie van (minderjarige) verdachten, ${ }^{4}$ waarvan Richtlijn 2013/48/EU en Richtlijn 2016/800/EU van belang zijn geweest voor het recht op rechtsbijstand aan minderjarige verdachten. Richtlijn 2013/48/EU betrof de versterking van rechten van alle verdachten $^{5}$ en Richtlijn 2016/800/EU betrof specifiek de rechten van minderjarige verdachten en beklaagden. ${ }^{6}$ Op grond van deze richtlijnen kan geen algemeen recht op rechtsbijstand aan alle verdachten worden ontleend; slechts in situaties waarin sprake is van vrijheidsbeneming. ${ }^{7}$ Richtlijn 2016/800/EU moest voor 11 juni 2019 zijn geïmplementeerd in de Nederlandse wetgeving. Het wetsvoorstel tot implementatie van de EU-richtlijn ${ }^{8}$ werd onder andere bekritiseerd door de Nederlandse Orde van Advocaten (NOvA), die een uitgebreid advies had geschreven over het wetsvoorstel, waarna het voorgestelde artikel $489 \mathrm{~Sv}$ werd aangepast. De NOvA had er terecht op gewezen dat de richtlijn aldus moet worden gelezen dat ook de mogelijkheid om afstand te doen van verhoorbijstand wordt uitgesloten. ${ }^{9}$ Per 1 juni 2019 bepaalt het nieuwe artikel 489 lid 2 Sv dat artikel $28 \mathrm{a} \mathrm{Sv}$ niet van toepassing is. Artikel $28 \mathrm{a} \mathrm{Sv}$ bepaalt dat de aangehouden verdachte vrijwillig en ondubbelzinnig afstand kan doen van het recht op rechtsbijstand overeenkomstig het Wetboek van Strafvordering. Aangezien dit artikel voor minderjarigen in artikel 489 lid $2 \mathrm{~Sv}$ buiten toepassing is verklaard, kan de minderjarige aangehouden verdachte geen afstand meer doen van verhoorbijstand. Afstand doen van consultatiebijstand is sinds 1 maart 2017 al niet meer mogelijk. ${ }^{10}$ De verplichte verhoorbijstand is vanzelfsprekend goed nieuws voor alle minderjarige aangehouden verdachten, maar niet zozeer voor de jeugdstrafrechtadvocaten, die tegen een vaste lage vergoeding alle verhoren dienen bij te

4. De andere twee richtlijnen betreffen Richtlijn 2010/64/EU van het Europees Parlement en de Raad van 20 oktober 2010 betreffende het recht op vertolking en vertaling in strafprocedures en Richtlijn 2012/13/EU van het Europees Parlement en de Raad van 22 mei 2012 betreffende het recht op informatie in strafprocedures.

5. Richtlijn 2013/48/EU van het Europees Parlement en de Raad van 22 oktober 2013 betreffende het recht op toegang tot een advocaat in strafprocedures en in procedures ter uitvoering van een Europees aanhoudingsbevel en het recht om een derde op de hoogte te laten brengen vanaf de vrijheidsbeneming en om met derden en consulaire autoriteiten te communiceren tijdens de vrijheidsbeneming (PbEU L 294).

6. Richtlijn 2016/800/EU van het Europees Parlement en de Raad van 11 mei 2016 betreffende procedurele waarborgen voor kinderen die verdachte of beklaagde zijn in een strafprocedure (PbEU L 132).

7. Kamerstukken // 2018/19, 35116, nr. 3, p. 11

8. Kamerstukken // 2018/19, 35116, nr. 3, Wetsvoorstel tot Wijziging van het Wetboek van Strafvordering en de Overleveringswet ter implementatie van richtlijn nr. 2016/800/EU van het Europees Parlement en de Raad van 11 mei 2016 betreffende procedurele waarborgen voor kinderen die verdachte of beklaagde zijn in een strafprocedure (PbEU L 132).

9. Kamerstukken // 2018/19, 35116, nr. 3, p. 11

10. Art. 489 lid 1 (oud) Sv: 'De verdachte geen kan afstand doen van het in artikel $28 \mathrm{c}$ bedoelde onderhoud met de raadsman voorafgaand aan het verhoor.' wonen. ${ }^{11} \mathrm{Na}$ een brandbrief van jeugdrechtadvocaten en een overleg met de Minister voor Rechtsbescherming (Dekker) werd de vergoeding aan de jeugdstrafrechtadvocaten verhoogd. ${ }^{12}$

Richtlijn 2016/800/EU betreft niet alleen de rechtsbijstand aan minderjarigen, maar ook andere rechten, die per 1 juni 2019 hun beslag kregen in het Wetboek van Strafvordering. Zo bevat artikel $488 \mathrm{a} \mathrm{Sv}$ het recht op informatie van de verdachte die wordt aangehouden, bijvoorbeeld over het recht om door ouders, voogd of vertrouwenspersoon vergezeld te worden tijdens de procedure (art. 488ab Sv), dat ouders van de vrijheidsbeneming op de hoogte worden gesteld (zie ook art. 27 lid 1 Ambtsinstructie), van de mogelijkheid van audiovisuele verhoren (art. 488ac Sv), van het recht op medisch onderzoek (art. 489a Sv) en van het recht op een advies over zijn persoonlijkheid en zijn levensomstandigheden (art. 494a Sv). ${ }^{13} \mathrm{Bij}$ de oproeping om in raadkamer te worden gehoord met betrekking tot een bevel gevangenhouding ex artikel 493 lid $4 \mathrm{~Sv}$, wordt krachtens artikel 488aa lid $3 \mathrm{~Sv}$ mededeling gedaan van het recht op vaststelling van een zo kort mogelijk passende duur van de voorlopige hechtenis, en de mogelijkheid van schorsing van de tenuitvoerlegging van het bevel voorlopige hechtenis, het recht vergezeld te worden door de ouders of voogd of een vertrouwenspersoon, het recht op periodieke toetsing van de voorlopige hechtenis en het recht om bij het ondergaan van voorlopige hechtenis gescheiden van volwassenen te verblijven.

\section{Wet herziening tenuitvoerlegging strafrechtelijke beslissingen}

Per 1 januari 2020 zijn de Wet herziening tenuitvoerlegging strafrechtelijke beslissingen ${ }^{14}$ (Wet USB), de Invoeringswet herziening tenuitvoerlegging strafrechtelijke beslissingen, ${ }^{15}$, het Invoeringsbesluit herziening tenuitvoerlegging strafrechtelijke beslissingen en het Besluit tenuitvoerlegging strafrechtelijke beslissingen in werking getreden. ${ }^{16}$ Deze wetten en

11. S. Droogleever Fortuyn, 'Hoe Sander Dekker zwichtte', Advocatenblad, 1 oktober 2019 via https://www.advocatenblad.nl/2019/10/01/hoesander-dekker-zwichtte/.

12. Kamerstukken I/ 2018/19, 31753, nr. 178, Brief regering d.d. 2 september 2019; Vergoedingen strafpiket jeugdrechtadvocatuur.

13. Zie over deze materie ook: $M$. Jeltes, 'De rechtspositie van aangehouden minderjarige verdachten in de eerste fase van het strafrechtelijk onderzoek', Boom Strafblad 2020, 1, p. 20-26.

14. Met uitzondering van art. I, onderdeel I, art. II, onderdeel Z, en art. III wet van 22 februari 2017, houdende wijziging van het Wetboek van Strafrecht, het Wetboek van Strafvordering en enige andere wetten in verband met een herziening van de wettelijke regeling van de tenuitvoerlegging van strafrechtelijke beslissingen (Wet herziening tenuitvoerlegging strafrechtelijke beslissingen), Stb. 2017, 82.

15. Met uitzondering van art. IV

16. Besluit van 18 december 2019 , houdende vaststelling van het tijdstip van inwerkingtreding van de Invoeringswet herziening tenuitvoer- 
besluiten wijzigden onder meer het Wetboek van Strafrecht en het Wetboek van Strafvordering, waarin Boek 6 met de titel 'Tenuitvoerlegging' werd toegevoegd, maar bijvoorbeeld ook de vertrouwde artikelen $89 \mathrm{~Sv}$ en 591a Sv werden vernummerd naar artikel 533, respectievelijk artikel $530 \mathrm{~Sv}$. De implementatie van deze wetgeving verliep echter niet vlekkeloos. Zo worstelde de rechtspraak met de vordering tot tenuitvoerlegging wegens niet-naleving van een algemene voorwaarde. Artikel 6:6:7 Sv en artikel 6:6:21 lid 1 sub a juncto artikel 6:6:22 lid $1 \mathrm{~Sv}$ impliceerden dat hoger beroep tegen de toewijzingen van een vordering tot tenuitvoerlegging wegens niet-naleving van een algemene voorwaarde was uitgesloten. ${ }^{17}$ Verschillende rechtbanken ${ }^{18}$ wierpen in beslissingen na 1 januari 2020 de vraag op of de nieuwe wetssystematiek verenigbaar is met artikel 5 en 6 EVRM. Het feit dat alleen tegen het vonnis met betrekking tot de nieuwe verdenking hoger beroep ingesteld zou kunnen worden en niet tegen de beslissing over de vordering tenuitvoerlegging, kan met zich meebrengen dat bij een vrijspraak een betrokkene de voorwaardelijke straf heeft moeten ondergaan, terwijl de beslissing over het nieuwe feit dus geen stand houdt. ${ }^{19}$ In verschillende uitspraken kwam de verenigbaarheid met de onschuldpresumptie aan de orde. ${ }^{20}$ Op 6 maart 2020 wees de Hoge Raad arrest naar aanleiding van de ingediende vordering tot cassatie in het belang der wet. ${ }^{21}$ De Hoge Raad oordeelde dat 'indien de verdachte - binnen de grenzen van artikel $404 \mathrm{~Sv}$ - hoger beroep instelt tegen het vonnis, dat hoger beroep zich tevens uitstrekt tot de beslissing op de vordering tot tenuitvoerlegging van de voorwaardelijk opgelegde sanctie wegens niet-naleving van de daarbij gestelde algemene voorwaarde'. ${ }^{22}$

Vervolgens werd een Spoedreparatiewet Wet $\mathrm{USB}^{23}$ aangeboden, die per 25 juli 2020 in werking is getre-

legging strafrechtelijke beslissingen, de Wet herziening tenuitvoerlegging strafrechtelijke beslissingen, het Invoeringsbesluit herziening tenuitvoerlegging strafrechtelijke beslissingen en het Besluit tenuitvoerlegging strafrechtelijke beslissingen

17. Het was voor de invoering van de Wet USB al niet mogelijk om een rechtsmiddel in te stellen tegen een beslissing op een vordering tot tenuitvoerlegging wegens schending van een bijzondere voorwaarde (art. 14j lid 1 (oud) Sr). Zie ook HR 24 oktober 1995, ECLI:NL:HR: 1995:ZD0261.

18. O.a. Rb. Gelderland 13 januari 2020, ECLI:NL:RBGEL:2020:146; Rb. Gelderland 13 januari 2020, ECLI:NL:RBGEL:2020:147; Rb. NoordNederland 28 januari 2020, ECLI:NL:RBNNE:2020:378; Rb. Rotterdam 21 januari 2020, ECLI:NL:RBROT:2020:565; Hof Den Haag 31 januari 2020, ECLI:NL:GHDHA:2020:128; Rb. Rotterdam 31 januari 2020, ECLI:NL:RBROT:2020:693; Rb. Oost-Brabant 3 februari 2020, ECLI:NL:RBOBR:2020:510; Rb. Limburg 3 februari 2020, ECLI:NL:RBLIM:2020:810.

19. Zie ook Rb. Gelderland 13 januari 2020, ELCI:NL:RBGEL:2020:146.

20. Zie Parket bij de Hoge Raad 18 februari 2020, ECLI:NL:PHR:2020:160.

21. HR 6 maart 2020, ECLI:NL:HR:2020:389.

22. HR 6 maart 2020, ECLI:NL:HR:2020:389, r.o. 6.4 .

23. Wet van 24 juni 2020 tot wijziging van het Wetboek van Strafvordering en enkele andere wetten in verband met het doorvoeren van enkele noodzakelijke reparaties en andere kleine wijzigingen (Spoedreparatiewet herziening tenuitvoerlegging strafrechtelijke beslissingen), Stb. 2020, 225. den, ${ }^{24}$ aangezien bleek dat de wetgever steken had laten vallen. Dit wetsvoorstel wijzigt het Wetboek van Strafvordering $(\mathrm{Sv})$, het Wetboek van Strafrecht $(\mathrm{Sr})$ en enkele andere wetten vanwege onvolkomenheden die zijn geconstateerd sinds de inwerkingtreding per 1 januari 2020 van de Wet herziening tenuitvoerlegging strafrechtelijke beslissingen (en de Invoeringswet herziening tenuitvoerlegging strafrechtelijke beslissingen). Enkele correcties kenden grote spoed, zoals het herstellen van rechtsmiddelen die (abusievelijk) waren geschrapt bij het overzetten van de tenuitvoerleggingsbepalingen uit het Wetboek van Strafrecht naar het Wetboek van Strafvordering, aldus de memorie van toelichting. ${ }^{25}$ In de Spoedreparatiewet werd ook artikel 6:6:22 Sv aangepast: er staat hoger beroep open tegen de beslissing van de rechter tot (gedeeltelijke) tenuitvoerlegging van een voorwaardelijke straf of maatregel in geval van schending van de algemene voorwaarde (art. 6:6:21 lid 1 sub a Sv). Hoewel de Hoge Raad duidelijk had gemaakt dat de bevoegdheid daartoe berust op artikel 361a Sv juncto artikel 407 lid $1 \mathrm{~Sv}$, werd aanpassing van artikel 6:6:22 Sv wenselijk geacht. ${ }^{26}$

\subsection{Wijzigingen in het jeugdstrafrecht}

In deze paragraaf worden de belangrijkste wijzigingen met betrekking tot het jeugdstrafprocesrecht als gevolg van de invoering van de Wet USB uiteengezet.

\subsubsection{Besluit tenuitvoerlegging strafrechtelijke beslissingen} Het besluit tenuitvoerlegging jeugdstrafrecht 1994, dat onder andere regelgeving bevatte met betrekking tot de bijzondere voorwaarden bij schorsing van de voorlopige hechtenis, heeft plaats gemaakt voor het Besluit tenuitvoerlegging strafrechtelijke beslissingen (Besluit USB). Dit betekent dat voorwaarden die bij schorsing van de voorlopige hechtenis kunnen worden opgelegd, vanaf 1 januari 2020 te vinden zijn in het Besluit USB. Volgens artikel 493 lid $6 \mathrm{~Sv}$ kan de rechter, na advies te hebben ingewonnen bij de Raad voor de Kinderbescherming, naast de algemene voorwaarden genoemd in artikel 80 lid $2 \mathrm{~Sv}$, bijzondere voorwaarden aan de schorsing van de voorlopige hechtenis verbinden. De jeugdige moet met deze voorwaarde(n) instemmen. Artikel 2:6 lid 1 Besluit USB bevat deze bijzondere voorwaarden, waaronder het volgen van een leerproject van ten hoogste 120 uur (art. 2:6 lid 1 sub c Besluit USB). In het Besluit USB staan ook bepalingen over de PIJ-verlenging (art. 2:18 Besluit USB). Tevens wordt de procedure van de (voorwaardelijke) beëindiging van de PIJmaatregel door de Minister voor Rechtsbescherming (art. 6:2:22 lid $3 \mathrm{~Sv}$ ) uit de doeken gedaan. Zo bepaalt artikel 2:10 lid 1 Besluit USB dat de Minister voor Rechtsbescherming de maatregel van plaatsing in een inrichting voor jeugdigen te allen tijde voorwaardelijk of onvoorwaardelijk kan beëindigen indien het doel van de

24. Besluit van 16 juli 2020, houdende vaststelling van het tijdstip van inwerkingtreding van de Spoedreparatiewet herziening tenuitvoerlegging strafrechtelijke beslissingen, Stb. 2020, 286.

25. Kamerstukken I/ 2019/20, 35436, nr. 3.

26. Kamerstukken // 2019/20, 35436, nr. 3, p. 7. 
maatregel bereikt is of beter op andere wijze kan worden bereikt. Daarnaast zijn bepalingen over de gedragsbeinvloedende maatregel (GBM) in het Besluit USB opgenomen. In artikel 3:26 lid 1 Besluit USB staat dat een programma in het kader van een GBM kan bestaan uit een of meer gedragsinterventies. ${ }^{27}$ Ook staan in het Besluit USB bepalingen over gratie, de strafbeschikking, de tenuitvoerlegging van taakstraffen, betaling van geldboeten en de schadevergoedingsmaatregel. Gezien de veelzijdigheid van de bepalingen in het Besluit USB is kennis van dit besluit onontbeerlijk, in relatie tot de tenuitvoerlegging van vonnissen en strafbeschikkingen van zowel jeugdigen als volwassenen.

\subsubsection{Tenuitvoerlegging taakstraf}

Artikel 6:1:14 Sv bepaalt dat voor zover niet bij of krachtens de wet anders is bepaald, de bepalingen uit Boek 6 (Tenuitvoerlegging) van overeenkomstige toepassing zijn op de tenuitvoerlegging van rechterlijke beslissingen en strafbeschikkingen die op grond van Titel VIII A van het Eerste Boek van het Wetboek van Strafrecht (art. 77a tot en met 77gg Sr) zijn opgelegd aan jeugdige personen. Met betrekking tot de tenuitvoerlegging van de taakstraf is voor jeugdigen een uitzondering op de hoofdregel voor volwassenen (achttien maanden na onherroepelijk vonnis, negen maanden na onherroepelijke strafbeschikking, art. 6.3:1 lid $1 \mathrm{~Sv})$. De termijn waarbinnen de werk- of leerstraf moet zijn verricht bedraagt ten hoogste negen maanden indien niet meer dan honderd uren is opgelegd en overigens ten hoogste achttien maanden (art. 6:3:8 Sv). Voorheen was de termijn voor tenuitvoerlegging zes maanden, respectievelijk een jaar (art. $77 \mathrm{~m}$ lid 3 en 5 (oud) Sr) en was nog verlenging van die termijn mogelijk (art. $77 \mathrm{~m}$ lid 3 , 5 en 8 (oud) Sr), maar de desbetreffende bepalingen zijn komen te vervallen. Op grond van de algemene bepaling van artikel $6: 3: 1 \mathrm{~Sv}$ geldt ook voor jeugdigen dat de tenuitvoerleggingstermijn wordt verlengd met de tijd dat de veroordeelde vastzit of ongeoorloofd afwezig is. Een groot aantal taakstraffen opgelegd aan jeugdigen kon in verband met COVID-19 per 16 maart 2020 niet ten uitvoer gelegd worden. ${ }^{28}$ In de brief van de Minister voor Rechtsbescherming aan de Tweede Kamer van 9 juli 2020 schrijft hij dat er digitale mogelijkheden zijn ingezet om contact te houden met jongeren en er weer gestart is met de uitvoering van takstraffen binnen de kaders van het RIVM. Zowel bij Halt als bij werk- en leerstraffen die de Raad voor de Kinderbescherming uitvoert, wordt een deel van de afdoening of straf

27. Gedragsinterventies dienen te zijn erkend of voorlopig erkend door een door de Minister van Justitie en Veiligheid aan te wijzen commissie van gedragswetenschappers, de Erkenningscommissie gedragsinterventies justitie.

28. Minister Dekker heeft besloten dat de werk- en leerstraffen tijdelijk stoppen vanaf 16 maart. Dit omdat jongeren op veel projecten niet meer worden toegelaten en de veiligheid en gezondheid van jongeren op projecten niet meer kan worden gewaarborgd. De leerstraffen worden zo veel mogelijk uitgevoerd via leren op afstand. https:// www.kinderbescherming.nl/actueel/nieuws/2020/04/22/rvdk-werktdoor-tijdens-periode-met-coronavirus. digitaal uitgevoerd. ${ }^{29}$ Gezien de achterstanden die zijn ontstaan, is het maar de vraag hoe met deze dwingende termijn wordt omgegaan.

\subsubsection{Openbaarheid zittingen met betrekking tot tenuitvoerlegging}

Tot 1 januari 2020 waren raadkamerzittingen waarin bij beschikking werd beslist op de vordering tot verlenging of voorwaardelijke beëindiging van de PIJ besloten, ongeacht de leeftijd van de veroordeelde; artikel $77 \mathrm{u} \mathrm{Sr}$ (oud) verklaarde daartoe artikel $495 \mathrm{~b} \mathrm{~Sv}$ van toepassing. Per 1 januari zijn deze zittingen voor alle veroordeelden ingevolge artikel 6:6:4 lid $1 \mathrm{~Sv}$ in principe openbaar, tenzij sprake is van een veroordeelde die op het tijdstip dat de zaak dient de leeftijd van 18 jaar nog niet heeft bereikt. In dat geval zijn artikelen 495b (beslotenheid van zitting) tot en met 498 en $503 \mathrm{~Sv}$ van toepassing. Dit betekent dus dat in tegenstelling tot de periode voor 1 januari 2020, de vorderingen met betrekking tot PIJjeugdigen, die op het moment van behandeling tenminste 18 jaar zijn, openbaar zijn, of het nu de verlenging, terugplaatsing of omzetting van de PIJ-maatregel betreft. Hetzelfde geldt voor de vordering met betrekking tot een tijdelijke terugplaatsing gedurende een GBM - ook wel 'time-out' genoemd (art. 77wc lid 6 (oud) Sr, thans art. 6:6:35 lid $4 \mathrm{~Sv}$ ) - en voor de vordering tot verlenging van de GBM (art. 77wd (oud) Sr, thans art. 6:6:36 Sv). Dit lijkt opnieuw een lacune te zijn, gezien het feit dat vóór 1 januari 2020 alle (raadkamer)zittingen met betrekkking tot deze maatregelen besloten waren. $\mathrm{Bij}$ de behandeling van voornoemde vorderingen speelt het indexdelict veelal een grote rol en dit is juist tijdens de minderjarigheid gepleegd en de strafzaak is vervolgens achter gesloten deuren behandeld. Een openbare zitting met betrekking tot de tenuitvoerlegging van de zwaarste maatregelen in het jeugdstrafrecht lijkt dan ook in strijd met het uitgangspunt van het jeugdstrafrecht om re-integratie van de veroordeelde in de maatschappij te bevorderen, onder andere vanwege mogelijke stigmatisering. ${ }^{30}$

\subsubsection{Enkelvoudige behandeling met betrekking tot beslissingen over tenuitvoerlegging}

Op grond van artikel 6:6:1 lid 7 sub a Sv wordt een zaak over de tenuitvoerlegging behandeld en beslist door een enkelvoudige kamer, tenzij (1) sprake is van vrijheidsbeneming langer dan zes maanden indien het een jeugdzaak betreft, (2) de rechter die kennisneemt aanstonds oordeelt dat deze door een meervoudige kamer moet worden behandeld of (3) de zaak met betrekking tot de nieuwe verdenking door een meervoudige kamer wordt behandeld. De vordering tenuitvoerlegging wegens schending van de algemene voorwaarde wordt dan ook door de meervoudige kamer behandeld. Voorheen kon een vordering tot tenuitvoerlegging van een door een

29. Kamerstukken I/ 2019/20, 29741, nr. 77

30. Verhoging strafrechtelijke minimumleeftijd in context. Advies over verhoging van de strafrechtelijke minimumleeftijd en het belang van goede jeugdhulp, Den Haag: Raad voor Strafrechtstoepassing en Jeugdbescherming, 20 december 2017, p. 22 
meervoudige kamer voorwaardelijk opgelegd vonnis alleen door een meervoudige kamer worden behandeld; dat is nu dus niet meer het geval. Een vordering tot verlenging van de PIJ-maatregel wordt door de meervoudige kamer behandeld (art. 6:6:31 lid $4 \mathrm{~Sv}$ ). De vordering tot terugplaatsing in een justitiële jeugdinrichting (JJI) tijdens een voorwaardelijke beëindiging (art. 6:6:32 lid 3 sub c Sv) en de vordering tot omzetting van de PIJmaatregel in een tbs met een bevel tot dwangverpleging (art. 6:6:33 lid $1 \mathrm{~Sv}$ ) kunnen echter enkelvoudig worden behandeld, aangezien de wetgever hier niet uitdrukkelijk heeft bepaald dat deze beslissing voorbehouden is aan de meervoudige kamer. Gezien de grote consequenties van deze beslissingen voor de veroordeelde jeugdige, lijkt het echter aangewezen om deze vorderingen meervoudig te behandelen. Overigens luidde artikel 6:6:1 lid 7 Sv per 1 januari 2020 dat vorderingen tot tenuitvoerlegging strekkende tot vrijheidsbeneming van minder dan een jaar in beginsel worden behandeld door de enkelvoudige rechter. In jeugdzaken geldt op grond van artikel 495 lid 2 Sv echter een lagere grens: de (enkelvoudige) kinderrechter kan jeugddetentie tot zes maanden opleggen. Artikel 6:6:1 lid $7 \mathrm{~Sv}$ voldeed hier niet aan en moest dus worden aangepast door middel van de Spoedwet. Een vordering tenuitvoerlegging tot zes maanden jeugddetentie wordt in het vervolg dus door de enkelvoudige kamer behandeld), vorderingen met langere duur door de meervoudige kamer (art. 6:6:1 lid 7 sub a onder $1 \mathrm{~Sv})$.

\subsubsection{Strafonderbreking}

Het enigszins obscure artikel $77 \mathrm{j}$ (oud) $\mathrm{Sr}$ is verplaatst naar Boek 6, waar nu in artikel 6:2:4 Sv staat dat de Minister voor Rechtsbescherming in uitzonderlijke gevallen op verzoek van de betrokkene, het openbaar ministerie of ambtshalve de tenuitvoerlegging van een vrijheidsstraf tijdelijk kan onderbreken. Deze onderbreking duurt niet langer dan noodzakelijk (art. 6:2:4 lid 1 $\mathrm{Sv}$ ). In het vervallen artikel $77 \mathrm{j}$ (oud) $\mathrm{Sr}$ was nog een maximale termijn van drie maanden aan de strafonderbreking verbonden. De nieuwe bepaling spreekt dus van een noodzakelijke onderbreking. Deze bepaling is eveneens van toepassing op volwassenen.

\subsection{Lacunes met betrekking tot het jeugdstrafrecht}

In de vorige paragraaf zijn de belangrijkste wijzigingen ten opzichte van de situatie voor 1 januari 2020 uiteengezet. Voorgaande voorbeelden waren echter niet de enige wijzigingen die grotendeels nadelig zijn voor de jeugdige veroordeelde. Nadat de Spoedreparatiewet was ingediend, heeft de Minister voor Rechtsbescherming op 20 mei 2020 een nota van wijziging bij de Spoedreparatiewet aan de Tweede Kamer gestuurd. Deze nota van wijziging betrof aanvullende correcties van het Wetboek van Strafvordering en deze hadden alle betrekking op bepalingen inzake het jeugdstrafrecht. ${ }^{31}$ Deze correcties en de huidige stand van zaken worden in deze paragraaf

31. Kamerstukken // 2019/20, 35436, nr. 7 besproken en gelden per 25 juli 2020. Uit de formulering van de Spoedwet ${ }^{32}$ en het Besluit tot vaststelling van het tijdstip van inwerkingtreding van de Spoedreparatiewet, ${ }^{33}$ blijkt niet dat deze bepalingen met terugwerkende kracht zijn ingevoerd.

\subsubsection{Voormaardelijke invrijheidstelling}

In artikel $77 \mathrm{a} \mathrm{Sr}$ staat vermeld welke wettelijke bepalingen niet van toepassing zijn op jeugdigen van 12 tot 18 jaar. Hierin staan ook de bepalingen over de voorwaardelijke invrijheidstelling genoemd (art. 15 tot en met 151 (oud) Sr). Het jeugdstrafrecht kent niet dezelfde regeling als die voor volwassenen. ${ }^{34}$ Deze regeling is echter verplaatst naar het Wetboek van Strafvordering (art. 6:2:10 e.v. Sv), waarbij werd nagelaten artikel 77a $\mathrm{Sr}$ aan te passen. Opeens was dus de v.i.-regeling van toepassing op minderjarigen. De Spoedreparatiewet herstelt dit door toevoeging van artikel 6:2:13a Sv, waarin staat dat de v.i.-regeling niet van toepassing is op jeugdigen. ${ }^{35}$

\subsubsection{Rechtsmiddelen}

Als een jeugdige zich niet houdt aan de voorwaarden van de maatregel betreffende het gedrag (ook wel GBM genoemd), kan het openbaar ministerie de vervangende jeugddetentie toepassen (art. 6:6:35 jo. art. 6:3:10 Sv). Voor 1 januari 2020 kon de jeugdige tegen deze beslissing een bezwaarschrift indienen (art. $77 \mathrm{wc}$ Sr jo. art. $77 \mathrm{p} \mathrm{Sr}$ ). Deze mogelijkheid is verdwenen en moest weer hersteld worden in artikel 6:6:23 Sv.

Ook was het sinds 1 januari 2020 niet meer mogelijk om hoger beroep in te stellen tegen de beslissing tot terugplaatsing van een jeugdige in een inrichting ex artikel 6:6:32 lid 3 sub c Sv (voorheen art. 77tb Sr) en tegen de beslissing om de PIJ-maatregel om te zetten in tbs met dwangverpleging ex artikel 6:6:33 Sv (voorheen art. 77tc $\mathrm{Sr}$ ). Artikel 6:6:37 Sv is als gevolg van de Spoedwet aangepast teneinde deze rechtsmiddelen weer in het leven te roepen.

Tot 1 januari 2020 was het mogelijk om een bezwaarschrift in te dienen tegen de beslissing van het openbaar ministerie tot wijziging van de taakstraf wat betreft de aard van de te verrichten werkzaamheden (art. 6:3:9 lid $2 \mathrm{~Sv}$ ). Deze optie verdween met de Wet USB en wordt door de nota van wijziging hersteld, door in art. 6:6:23 lid $1 \mathrm{~Sv}$ het art. 6:3:9 lid $2 \mathrm{~Sv}$ toe te voegen.

Een raadsman had tot 1 januari 2020 dezelfde bevoegdheden als zijn cliënt onder de 16 jaar, zoals het instellen,

32. Wet van 24 juni 2020 tot wijziging van het Wetboek van Strafvordering en enkele andere wetten in verband met het doorvoeren van enkele noodzakelijke reparaties en andere kleine wijzigingen (Spoedreparatiewet herziening tenuitvoerlegging strafrechtelijke beslissingen), Stb. 2020, 225 .

33. Besluit van 16 juli 2020 , houdende vaststelling van het tijdstip van inwerkingtreding van de Spoedreparatiewet herziening tenuitvoerlegging strafrechtelijke beslissingen, Stb. 2020, 286.

34. Er is een jeugdspecifieke regeling van voorwaardelijke invrijheidstelling in art. 6:6:28 Sv, maar die heeft een geheel andere strekking dan die voor volwassenen.

35. Kamerstukken I/ 2019/20, 35436, nr. 3, p. 3. 
intrekken of afstand doen van een rechtsmiddel (art. 503 (oud) Sv). Als een jeugdige onder de zestien het niet met de handeling van zijn raadsman eens was, kon hij een bezwaarschrift indienen. Per 1 januari 2020 was dit artikel opeens verdwenen. Door middel van de nota van wijziging is het artikel teruggeplaatst in het vernummerde artikel $502 \mathrm{~Sv}$.

Door de formulering van artikel 6:6:37 lid $3 \mathrm{~Sv}$ zoals dat per 1 januari 2020 luidde, kon worden afgeleid dat als er hoger beroep wordt ingesteld tegen een beslissing die betrekking heeft op de PIJ-maatregel, de veroordeelde in afwachting van de beslissing in vrijheid kan worden gesteld. Dit is gecorrigeerd in de nota van wijziging.

\subsubsection{Algemene bepalingen ten onrechte verplaatst}

De bepalingen over het in kennis stellen van ouders of voogd en de raadsman zijn van artikel $504 \mathrm{~Sv}$ (oud) verplaatst naar artikel 6:6:37 lid 4 en $5 \mathrm{~Sv}$ en vervolgens bij de Spoedreparatiewet naar artikel 6:6:38, maar die zijn eveneens van toepassing op de procedure in eerste aanleg of in hoger beroep of cassatie. In het algemene gedeelte van het jeugdstrafprocesrecht waren deze bepalingen echter niet meer te vinden. Pas bij de nota van wijziging werd het artikel over de oproeping tijdens de procedure bij de rechtbank en het gerechtshof hersteld in artikel $503 \mathrm{~Sv}$. Ook het artikel waarin de algemene bepalingen over de beslotenheid van de zitting en aanwezigheidsplicht van ouder of voogd en de jeugdige tijdens de procedure bij de rechtbank en het gerechtshof werden teruggeplaatst in artikel $501 \mathrm{~Sv}$.

\subsubsection{Vervangende jeugddetentie bij schadevergoedingsmaatregel}

In de nieuwe strafvorderlijke bepalingen was de verwijzing naar artikel $771 \mathrm{Sr}$ verdwenen, waardoor bij de oplegging van de schadevergoedingsmaatregel in jeugdstrafzaken een bevel tot vervangende jeugddetentie weer mogelijk wordt indien volledige betaling of volledig verhaal uitblijft. Deze mogelijkheid bestaat dus naast de gijzeling. Dit betekent dat naast een eventueel bevel tot vervangende jeugddetentie, de rechter in elk geval de duur van de gijzeling dient te bepalen bij een betalingsonwillige veroordeelde (art. 6:4:20 Sv).

\subsubsection{Meldplicht bij jeugdreclassering}

Op grond van artikel 14c Sr wordt per 1 januari 2020 onder medewerking verlenen aan reclasseringstoezicht mede verstaan het melden bij de reclassering. In artikel $77 \mathrm{z} \mathrm{Sr}$, dat dezelfde strekking heeft, is dit echter niet aangepast. Door middel van de Spoedreparatiewet gebeurde dit alsnog.

\subsubsection{Voorlopige tenuitvoerlegging bij GBM en voorwaardelijke beëindiging PIf-maatregel}

In de artikelen betreffende de GBM (art. 6:6:32 Sv) en de voorwaardelijke beëindiging van de PIJ-maatregel (art. 6:6:32 Sv), is ten onrechte geen verwijzing naar de procedure bij de rechter-commissaris opgenomen, indien het openbaar ministerie de aanhouding van de veroordeelde noodzakelijk acht en een vordering tot voorlopige tenuitvoerlegging indient bij de rechtbank (voorheen art. $77 \mathrm{cca} \mathrm{Sr}$ ). Deze optie dient vanzelfsprekend wel behouden te worden en is door middel van de nota van wijziging bij de Spoedreparatiewet gecorrigeerd.

Kortom: de Wet USB was geen fraai staaltje wetgeving. Dat rechtsmiddelen in jeugdstrafzaken opeens verdwenen, procedurevoorschriften in jeugdstrafzaken verplaatst werden naar Boek 6 terwijl deze ook van toepassing waren op 'gewone' zittingen en zelfs de voorwaardelijke invrijheidstelling opeens van toepassing was in jeugdstrafzaken, is op zijn zachtst gezegd heel ongelukkig te noemen. Inmiddels hebben de voorgestelde wijzigingen met de inwerkingtreding van de Spoedreparatiewet op 25 juli jl. hun beslag gekregen in het Wetboek van Strafvordering, dan wel het Wetboek van Strafrecht en dienen professionals in de jeugdstrafrechtketen zich opnieuw bekend te maken met deze wijzigingen of herstelwerkzaamheden.

\section{Internationale ontwikkelingen}

Het VN-Kinderrechtencomité, dat toeziet op de naleving door verdragsstaten van de bepalingen van het Internationale Verdrag inzake de Rechten van het Kind (IVRK), heeft in 2019 een gezaghebbend commentaar, een General Comment, uitgevaardigd. Daarnaast hebben de Verenigde Naties een omvangrijk mondiaal onderzoek laten verrichten naar kinderen die te maken krijgen met vrijheidsbeneming. Deze ontwikkelingen worden in deze paragraaf toegelicht.

\subsection{General Comment 24}

Op 18 september 2019 verscheen General Comment No. 24 on children's rights in the child justice system, ${ }^{36}$ dat General Comment 10 on children's rights in juvenile justice uit $2007^{37}$ vervangt. In een General Comment geeft het $\mathrm{VN}-$ Kinderrechtencomité nadere invulling aan bepalingen van het Internationale Verdrag inzake de Rechten van het Kind (IVRK). ${ }^{38}$ Met betrekking tot het jeugdstraf(proces)recht zijn artikel 37 en 40 IVRK van belang. Het ontstaan van internationale en regionale standaarden, nieuwe inzichten over de ontwikkeling van kinderen en adolescenten en bewijs van de effectiviteit van praktijken zoals herstelrecht, hebben onder meer geleid tot het nieuwe General Comment. ${ }^{39}$ Het General Comment heeft onder andere tot doel om de voor het jeugdstrafrecht relevante verdragsbepalingen en princi-

36. General Comment No. 24 on children's rights in the child justice system, 18 september 2019, CRC/C/GC/24.

37. General Comment No. 10 on children's rights in juvenile justice, CRC/C/GC/10, 25 april 2007.

38. Zie ook: Y.N. van de Brink \& E.M. Mijnarends, 'General Comment No. 24 - nieuw elan voor het jeugdstrafrecht. Over leeftijdsgrenzen, "diversion" en de bredere implicaties voor het jeugdstrafrecht', Boom Strafblad, 2020, 1, p. 7-15.

39. GC No. 24, par. 1. 
pes in het huidige tijdsbeeld te plaatsen en de verdragsstaten te begeleiden naar een holistische implementatie van een jeugdstrafrechtsysteem dat de toepassing van kinderrechten stimuleert en kinderrechten beschermt. Andere doelen zijn het belang van preventie en vroegtijdige interventies te benadrukken en om strategieën te bevorderen die schadelijke effecten op kinderen die in contact komen met het jeugdstrafrecht te verminderen, bijvoorbeeld door alternatieve afdoeningen te bevorderen, zodat kinderen niet voor een (kinder)rechter dienen te verschijnen, en een passende minimumleeftijd voor strafrechtelijke aansprakelijkheid te bepalen. ${ }^{40} \mathrm{De}$ minimumleeftijd in de Nederlandse context wordt besproken in paragraaf 5.2.4.

Artikel 37 en 40 IVRK zijn de bepalingen die het jeugdstraf(proces)recht betreffen. ${ }^{41}$ Artikel 40 IVRK geeft rechtswaarborgen voor het jeugdstrafrecht, artikel 37 IVRK bevat specifieke bepalingen over vrijheidsbeneming. Artikel 40 lid 1 IVRK bepaalt dat de staten die partij zijn bij het verdrag het recht erkennen van ieder kind dat wordt verdacht van, vervolgd wegens of veroordeeld ter zake van het begaan van een strafbaar feit, op een wijze van behandeling die geen afbreuk doet aan het gevoel van waardigheid en eigenwaarde van het kind, die de eerbied van het kind voor de rechten van de mens en de fundamentele vrijheden van anderen vergroot, en waarbij rekening wordt gehouden met de leeftijd van het kind en met de wenselijkheid van het bevorderen van de herintegratie van het kind en van de aanvaarding door het kind van een opbouwende rol in de samenleving. Het jeugdstrafrecht staat derhalve ten dienste van de herintegratie van de jeugdige. In artikel 40 lid 2 IVRK is een aantal rechtswaarborgen voor een eerlijk proces opgesomd, zoals de onschuldpresumptie, het recht op rechtsbijstand, het recht op effectieve participatie tijdens de procedure, het recht op eerbiediging van het privéleven gedurende alle stadia van het strafrechtelijk onderzoek, recht op informatie over de beschuldiging en recht op een spoedige berechting. Het VN-Kinderrechtencomité benadrukt dat continue en systematische training van professionals in de jeugdstrafrechtketen cruciaal is om deze waarborgen te kunnen naleven. Deze professionals zouden in staat moeten zijn om in een interdisciplinair team te werken en op de hoogte moeten zijn van de lichamelijke, psychologische, mentale en sociale ontwikkeling van kinderen en adolescenten, net als van de behoeften van gemarginaliseerde kinderen. ${ }^{42}$

Het recht om gehoord te worden in het strafproces is een fundamenteel recht, aldus het Comité, en het Comité verwijst daarbij naar artikel 12 IVRK. Kinderen moeten rechtstreeks worden gehoord, en dus niet bij monde

40. GC No. 24, par. 6 .

41. Deze paragraaf is een bewerking van J.V.O.R. Doekhie, T. Liefaard, R. den Bak, M. Jeltes, A. Marchena-Slot, R. Nieuw \& F. van der Mooren, Invoering jeugdstrafrecht in Caribisch Nederland. Een verkenning naar een jeugdstrafrechtmonitor, Den Haag: Boom criminologie 2020, par. 2.2.1.

42. GC No. 24, par. 39 van een vertegenwoordiger, gedurende alle stadia van het strafproces en mogen ook zwijgen. Aan dit zwijgen mogen geen nadelige gevolgen verbonden worden. ${ }^{43}$ Een andere waarborg die voortvloeit uit artikel 40 lid 2 IVRK is het recht op effectieve participatie tijdens de strafrechtelijke procedure (art. 40 lid 2 (b) (iv) IVRK). Het Comité stelt dat een kind dat voldoet aan de minimumleeftijd voor strafrechtelijke aansprakelijkheid, ook competent is om te participeren in zijn of haar strafproces. Om effectief te participeren, moet een kind gesteund worden door alle professionals, teneinde de verdenking(en) en de eventuele gevolgen daarvan te begrijpen, om een rechtsbijstandverlener te kunnen instrueren, getuigen op te roepen, een verklaring te kunnen afleggen en om passende beslissingen te nemen met betrekking tot het bewijs, getuigenverklaringen en de straffen en/of maatregelen die opgelegd kunnen worden. Dit recht betekent ook dat de procedure verloopt in een taal die minderjarige volledig begrijpt en in een begrijpende atmosfeer, zodat kinderen volledig kunnen participeren. Hierbij kan ook gedacht worden aan kindvriendelijke taal tijdens alle stadia van de procedure, kindvriendelijke ruimten, steun door geschikte volwassenen, het zich ontdoen van intimiderende kleding (denk aan toga's) en het aanpassen van procedures, waarbij ook wordt gedacht aan kinderen met een handicap. ${ }^{44}$ In het kader van artikel 40 lid 2 (b) (viii) IVRK benadrukt het Comité dat jeugdstrafzaken zich achter gesloten deuren afspelen en dat de identiteit van kinderen niet geopenbaard mag worden, mocht de uitspraak wel openbaar zijn. ${ }^{45}$ Ook beveelt het Comité aan het strafblad van kinderen te verwijderen als zij 18 jaar zijn. Dit zou automatisch moeten gebeuren, of in exceptionele gevallen, na onafhankelijke toetsing. ${ }^{46}$

Artikel 40 lid 3 IVRK bepaalt vervolgens dat de lidstaten ernaar streven de totstandkoming te bevorderen van wetten, procedures, autoriteiten en instellingen die in het bijzonder bedoeld zijn voor kinderen die worden verdacht van, vervolgd wegens of veroordeeld wegens van het begaan van een strafbaar feit, en in het bijzonder de invoering, wanneer passend en wenselijk, van maatregelen voor de handelwijze ten aanzien van deze kinderen zonder dat men zijn toevlucht neemt tot gerechtelijke stappen, mits de rechten van de mens en de wettelijke garanties volledig worden geëerbiedigd. Volgens het VN-Kinderrechtencomité dienen hieronder onder andere buitengerechtelijke afdoeningen te worden verstaan. Deze afdoeningen hebben als voordeel dat ze stigmatisering en een aantekening in de justitiële documentatie ('strafblad') voorkomen en daarnaast blijken ze kinderen positief te beïnloeden, blijken ze kostenefficient en in overeenstemming met de openbare veiligheid, aldus het VN-Kinderrechtencomité. ${ }^{47}$ 
Het Comité meent dat een buitengerechtelijke afdoening in de meerderheid van alle zaken toegepast zou moeten worden en dat staten deze voor een groot aantal delicten van toepassing zou moeten laten zijn, indien mogelijk ook voor ernstige feiten. Gerechtelijke afdoeningen zouden vanaf het begin van het strafrechtelijk onderzoek beschikbaar moeten zijn, tijdens de verschillende stadia van het strafproces, en geïntegreerd moeten worden in het strafrechtsysteem, waarbij de rechten van kinderen en rechtswaarborgen volledig gerespecteerd en beschermd worden. Het Comité benadrukt dat een gerechtelijke afdoening alleen gebruikt kan worden als er voldoende belastend bewijs is dat de jeugdige het feit heeft gepleegd, dat de jeugdige uit eigen wil het feit bekent, zonder intimidatie of druk en dat de bekentenis niet later alsnog gebruikt wordt in een strafrechtelijke procedure. ${ }^{48}$ De aard en de duur van de gerechtelijke afdoening kan veel eisen van een jeugdige, daarom is juridische of andere passende bijstand noodzakelijk. ${ }^{49}$

Lid 3 sub a van artikel 40 IVRK bepaalt dat staten een minimumleeftijd voor strafrechtelijke aansprakelijkheid in de wet zouden moeten vastleggen. Het VN-Kinderrechtencomité beveelt in het General Comment aan de minimumleeftijd op ten minste 14 jaar te bepalen, maar gezien wetenschappelijke inzichten over het adolescentenbrein, moedigt het Comité verdragsstaten aan een leeftijd van 15 of 16 jaar te hanteren. ${ }^{50}$ In het vorige General Comment stelde het Comité nog 12 jaar als ondergrens voor de minimumleeftijd voor strafrechtelijke aansprakelijkheid, waarbij een hogere minimumleeftijdsgrens van 14 of 16 jaar werd aangemoedigd. ${ }^{51}$

Artikel 40 lid 4 IVRK schrijft vervolgens voor dat een verscheidenheid van regelingen, zoals rechterlijke bevelen voor zorg, begeleiding en toezicht, adviezen, jeugdreclassering, pleegzorg, programma's voor onderwijs en beroepsopleiding en andere alternatieven voor institutionele zorg beschikbaar dienen te zijn om te verzekeren dat de handelwijze ten aanzien van kinderen hun welzijn niet schaadt en in de juiste verhouding staat zowel tot hun omstandigheden als tot het strafbare feit. Dit betekent ten eerste dat op de lidstaat een verplichting rust om te voorzien in een meerdere, gevarieerdere interventies voor jeugdigen en daarnaast dat die interventie proportioneel moet zijn ten opzichte van zowel de ernst van het feit als de persoonlijke omstandigheden van de jeugdige. Het VN-Kinderrechtencomité noemt hierbij de leeftijd, verminderde toerekenbaarheid, specifieke omstandigheden en behoeften en de geestelijke gezondheid van de jeugdige, alsook de verschillende, met name langetermijnbehoeften van de samenleving. ${ }^{52}$

Met betrekking tot artikel 37 IVRK erkent het VN-Kinderrechtencomité dat vrijheidsbeneming schadelijke

\footnotetext{
48. GC No. 24, par. 16-18

GC No. 24, par. 72

GC No. 24, par. 22

GC No. 10, par. 32-33.

GC No. 24, par. 76.
}

effecten heeft voor jeugdigen, die een negatieve impact kunnen hebben op de herintegratie van jeugdigen en het beveelt dan ook aan maximumstraffen in te voeren die passen bij het principe 'straffen voor de kortst mogelijke duur'. ${ }^{53}$

Mocht vrijheidsbeneming toegepast moeten worden, dan biedt artikel 37 IVRK waarborgen. Het VN-Kinderrechtencomité vat deze samen in het General Comment als leidende beginselen, te weten dat (a) de aanhouding, voorlopige hechtenis of detentie alleen in overeenstemming met de wet mag worden toegepast, alleen als ultimum remedium en voor de kortst mogelijke duur en (b) dat de vrijheidsbeneming van een kind niet onwettig of willekeurig mag zijn. Het comité benadrukt dat kinderen niet in politiecellen geplaatst mogen worden, alleen als het niet anders kan en voor de kortst mogelijke duur. Ook mogen kinderen niet samen met volwassenen in cellen geplaatst worden, behalve als dat in hun belang is. ${ }^{54}$ Het Comité gaat zelfs zover om de staten aan te bevelen bij geen enkel kind vrijheidsbeneming toe te passen, behalve als er gevaar is voor de openbare veiligheid of gezondheid. Het Comité moedigt staten aan een leeftijdsgrens van 16 jaar in te stellen voor vrijheidsbeneming. ${ }^{55}$ Het is wat Van den Brink en Mijnarends betreft hoog tijd dat de professionele actoren die zich bezighouden met het jeugdstrafrecht, in het bijzonder de rechtspraktijk, actiever en explicieter gebruik gaan maken van het IVRK en General Comment No. 24. 'Slechts dan bieden deze kinderrechtelijke instrumenten daadwerkelijk rechtsbescherming aan jeugdigen en kunnen zij daadwerkelijk nieuw elan geven aan de Nederlandse jeugdstrafrechtspleging', 56

\subsection{UN Global Study on Children Deprived of Liberty}

Eind 2019 verscheen een lijvig rapport over vrijheidsbeneming van kinderen. Prof. mr. dr. Ton Liefaard, UNICEF hoogleraar aan de Universiteit Leiden, heeft een bijdrage mogen leveren aan dit onderzoek in opdracht van de Verenigde Naties.

'Op 19 november 2019 verscheen het eindrapport van de Global Study on Children Deprived of Liberty, uitgevoerd in opdracht van de Algemene Vergadering van de Verenigde Naties onder leiding van independent expert professor Manfred Nowak. De studie had als doel, om beter inzicht te verschaffen in (de omvang van) het fenomeen 'vrijheidsbeneming van kinderen' en om 'best practices' te identificeren die zouden kunnen bijdragen aan een betere implementatie van het IVRK op dit punt (art. 37 (b)-(d) IVRK). De studie richt zich op verschillende vormen van vrijheidsbeneming: detentie in het jeugdstrafrecht, vrijheidsbeneming van kinderen samen met hun pri-

\footnotetext{
53. GC No. 24, par. 77

54. GC No. 24, par. 85

55. GC No. 24, par. 89

56. Y.N. van de Brink \& E.M. Mijnarends, 'General Comment No. 24 nieuw elan voor het jeugdstrafrecht. Over leeftijdsgrenzen, "diversion" en de bredere implicaties voor het jeugdstrafrecht', Boom Strafblad, 2020, 1, p. 7-15.
} 
maire verzorgers (zoals ouders), detentie in het migratiesysteem, vrijheidsbeneming in instellingen (zoals bijv. jeugdbeschermingsinstellingen), detentie in de context van gewapende conflicten en detentie op grond van nationale veiligheid. De studie benadrukt dat vrijheidsbeneming een aanzienlijke inbreuk op het leven van kinderen met zich brengt en vaak gepaard gaat met een negatieve impact op hun fysieke en psychische welzijn. Op basis van kwalitatieve en kwantitatieve data maakt de studie een inschatting van het aantal kinderen dat van hun vrijheid is beroofd. Het zou hierbij gaan om ten minste 1,5 miljoen kinderen per jaar, maar mogelijk feitelijk om meer dan 7 miljoen kinderen per jaar. Met name in (residentiële) instellingen zitten wereldwijd veel kinderen gevangen. Helaas komt geweld tegen kinderen die van hun vrijheid zijn beroofd vaak voor. Een belangrijke oorzaak voor de veelvuldige vrijheidsbeneming van kinderen is het gebrek aan adequate ondersteuning van gezinnen, zorgverleners en gemeenschappen bij de zorg voor kinderen. In het strafrecht is het gebruik van vrijheidsbeneming vooral te koppelen aan zero-tolerance beleid dat zich bijvoorbeeld manifesteert via lage leeftijdsgrenzen voor strafrechtelijke aansprakelijkheid en de criminalisering van kleinere vergrijpen.' 57

Met betrekking tot vrijheidsbeneming op grond van het strafrecht vermeldt het rapport dat naar schatting jaarlijks 410.000 kinderen in voorlopige hechtenis of detentie verblijven. Het rapport wordt afgesloten met aanbevelingen. Zo zouden staten het aantal kinderen in detentie moeten terugdringen, onder meer door de oorzaken die leiden tot detentie aan te pakken. Ook moedigt Nowak aan dat staten een nationaal actieplan maken waarin doelen worden opgenomen teneinde het aantal kinderen in verschillende vormen van vrijheidsbeneming te verminderen. Staten dienen ook te investeren in ondersteuning aan gezinnen en in de jeugdhulp. Staten dienen zich ook te houden aan artikel 37 (b) IVRK, dat bepaalt dat vrijheidsbeneming een measure of last resort is. Staten moeten de leeftijd voor strafrechtelijke aansprakelijkheid op mimimaal 14 jaar vastleggen en alternatieven voor rechterlijke afdoening moeten toepassen. ${ }^{58}$ Met betrekking tot deze laatste drie aanbevelingen dient Nederland dus nog stappen te maken, nu voorlopige hechtenis veelvuldig wordt toegepast, Nederland een minimumleeftijd van 12 jaar hanteert en er een beperkt aanbod is aan alternatieven voor strafrechtelijke afdoening en bijvoorbeeld een geslaagde mediation veelal nog tot een zitting bij de kinderrechter leidt.

\section{Beleid van het Ministerie van Justitie \& Veiligheid}

Deze paragraaf bespreekt de belangrijkste (voorgenomen) beleidswijzigingen van de zijde van het Ministerie van Justitie en Veiligheid.

\subsection{DNA-afname minderjarigen}

Op 3 april 2018 kondigde de Minister van Justitie en Veiligheid (Grapperhaus) een wetswijziging aan, die inhoudt dat voor minderjarigen na veroordeling slechts nog een bevel tot DNA-afname kan worden verstrekt bij een taakstraf van 40 uur of meer. Met betrekking tot twee zaken tegen Nederland ${ }^{59}$ heeft het VN-mensenrechtencomité in 2017 geoordeeld dat verplichte DNAafname van een minderjarige veroordeelde niet proportioneel is ten opzichte van het legitieme doel van het voorkomen en opsporen van serieuze misdrijven. Het VN-comité verzocht Nederland uiterlijk 3 april 2018 inlichtingen te verschaffen over de maatregelen waarmee aan de oordelen van het VN-comité gevolg zal worden geven. Daarnaast leidt het pedagogisch karakter van het jeugdstrafrecht, dat onder meer voortvloeit uit het Internationaal Verdrag inzake de Rechten van het Kind, ertoe dat aan minderjarigen, anders dan aan meerderjarigen, voor vergelijkbare strafbare feiten vaker een taakstraf wordt opgelegd dan een geldboete. Het ongewenste neveneffect daarvan is dat zij vaker dan meerderjarigen hun celmateriaal moeten afstaan en hun DNA-profiel daardoor vaker in de DNA-databank wordt opgeslagen, aldus de minister. De minister meent dat taakstraffen van 40 uur en meer worden opgelegd voor zware strafbare feiten en daarmee verband houdende omstandigheden. In die gevallen vindt hij het verdedigbaar en proportioneel dat celmateriaal van de minderjarige wordt afgenomen en zijn daaruit verkregen DNA-profiel in de DNA-databank wordt opgenomen. De bewaartermijnen van de opgeslagen DNA-profielen, identificerende gegevens (o.a. vingerafdrukken en handpalmafdrukken), justitiële en strafvorderlijke gegevens worden daarnaast gehalveerd. ${ }^{60}$ Dit voornemen heeft de minister begin 2019 nog herhaald in een brief aan de Tweede Kamer, ${ }^{61}$ maar tot op heden is er nog geen wetsvoorstel ingediend. Het voornemen van minister Grapperhaus om DNA-afname bij een veroordeelde minderjarige te beperken tot taakstraffen van 40 uur of meer leidde tot een aantal gegrondverklaringen van bezwaarschriften tegen de verwerking van DNA van minderjarigen in de DNA-database ten aanzien van taakstraffen van minder dan 40 uur, waarbij de rechtbanken verwezen naar de brief van de minister en de uitspraken van het $\mathrm{VN}$-comité.
57. T. Liefaard, 'Jaaroverzicht internationale kinderrechten 2019', Tijdschrift voor Familie- en Jeugdrecht, 2020/31.

58. Manfred Nowak, United Nations Global Study on Children Deprived of Liberty, UN Doc. GA A/74/136. https://www.ohchr.org/EN/HRBodies/ CRC/StudyChildrenDeprivedLiberty/Pages/Index.aspx.
59. VN-mensenrechtencomité 18 juli 2017, S.L. t. Nederland (2362/2013) en N.K.t. Nederland (2326/2013).

60. Kamerstukken I/ 2017/18, 31415, nr. 20

61. Kamerstukken I/ 2018/19, 31415, nr. 22. 
5.2 Aanpak jeugdcriminaliteit

Op 28 juni 2019 verscheen een brief van de Minister voor Rechtsbescherming aan de Tweede Kamer over de aanpak van de jeugdcriminaliteit. ${ }^{62}$ De minister kondigde daar aan in te zetten op meer maatwerk bij vrijheidsbeneming en nazorg, betere aansluiting bij de ernst van het delict om herhaling te voorkomen, een snellere reactie op strafbare feiten of overtreding van voorwaarden en meer interventiemogelijkheden bij specifieke delicten en problematiek. ${ }^{63}$

\subsubsection{Kleinschalige Voorzieningen E FFI's}

Met betrekking tot het eerste punt (meer maatwerk) schrijft de minister dat de jaarrapportage van de monitor van de Kleinschalige Voorziening (KV) in Amsterdam 2018 concludeert dat een Kleinschalige Voorziening een waardevolle toevoeging is aan het aanbod voor justitiële jeugd. 'De Kleinschalige Voorziening in Amsterdam wordt dan ook gecontinueerd na 2019 en de komende jaren komen daar nog twee Kleinschalige Voorzieningen voor strafrechtelijke jongeren bij in Rotterdam en Den Haag'. ${ }^{64}$ In de Kleinschalige Voorziening in Amsterdam kunnen maximaal acht jongens verblijven, die overdag naar hun dagbesteding gaan (school, stage, werk, sport) en 's nachts op grond van een bevel tot voorlopige hechtenis in de $\mathrm{KV}$ verblijven. Ook komen er twee gecombineerde KV's in de regio's Noord en Zuid, waar 'de inzet is om hier een voorziening te creëren met 16 bedden waarbij zowel strafrechtelijke als civielrechtelijke jongeren geplaatst kunnen worden' ${ }^{65}$

Ook werd in deze brief aangekondigd dat JJI's 't Keerpunt in Cadier en Keer en Juvaid te Veenhuizen moesten gaan sluiten. In Cadier en Keer, daar waar de JJI gesloten is, wordt bij voorkeur de $\mathrm{KV}$ in de regio Zuid gerealiseerd. ${ }^{66} \mathrm{De}$ (overgebleven) JJI's moeten zich gaan doorontwikkelen tot Landelijke Specialistische Voorzieningen. 'In deze voorziening krijgen jongeren met een specifiek profiel en/of, meervoudige problematiek, intensieve zorg en een hogere mate van (fysieke) beveiliging. De huidige groepsgerichte aanpak, zoals die in de JJI's gehanteerd wordt, verschuift naar een persoonsgerichte aanpak', aldus de minister. ${ }^{67}$ Er zijn per 1 januari 2021 vijf justitiële jeugdinrichtingen in Nederland, waarbij De Hunnerberg de enige inrichting is waar naast jongens ook meisjes in voorlopige hechtenis verblijven, dan wel gedetineerd of behandeld worden. ${ }^{68}$ Dit betekent dat slechts in de provincies Flevoland, Gelderland, Noord-Brabant en Zuid-Holland een justitiële jeugdinrichting is gevestigd, hetgeen problematisch is vanuit het oogpunt van resocialisatie van de jeugdige, gezien de

62. Kamerstukken I/ 2018/19, 28741, nr. 53.

63. Kamerstukken I/ 2018/19, 28741, nr. 53, p. 2.

64. Kamerstukken I/ 2018/19, 28741, nr. 53, p. 3

65. Kamerstukken I/ 2018/19, 28741, nr. 53, p. 3

66. Kamerstukken I/ 2018/19, 28741, nr. 53, p. 5

67. Kamerstukken I/ 2018/19, 28741, nr. 53, p. 4

68. Rijks Justitiële Jeugdinrichtingen (RJI) De Hartelborgt in Spijkenisse, Den Hey-Acker in Breda en De Hunnerberg in Nijmegen, en daarnaast de particuliere jeugdinrichtingen Lelystad en Teylingereind te Sassenheim. Zie https://www.dji.nl/locaties/justitiele-jeugdinrichtingen. potentieel grote afstand tot zijn of haar netwerk, school en stage.

\subsubsection{Behoud duur maximale jeugddetentie}

De Minister voor Rechtsbescherming kondigt in de brief tevens aan dat hij de maximale jeugddetentie (maximaal één jaar voor minderjarigen tussen de 12 en 16 jaar en twee jaar voor minderjarigen van 16 en 17 jaar, art. 77i Sr) niet gaat verhogen. Hij meent op grond van onderzoek dat lange straffen uiteindelijk leiden tot een hogere kans op recidive en dat het stelsel voldoende is toegerust op zeer ernstige delicten gelet op het feit dat de PIJ-maatregel maximaal zeven jaar kan duren en omgezet kan worden in een tbs met bevel tot dwangverpleging, en er een mogelijkheid is om bij 16- en 17-jarigen het volwassenenstrafrecht toe te passen. ${ }^{69}$

\subsubsection{Verblijf in de politiecel}

Op 28 januari 2020 verscheen het RSJ-advies Minderjarigen in de politiecel. Een advies over duur, verblijf en alternatieve locaties, waarin de RSJ de minister onder andere adviseerde het principe 'geen IVS, tenzij...' waarmee tijdens verschillende pilots ervaring was opgedaan, in de wet en het beleid vast te leggen. Daarnaast adviseerde de RSJ minderjarigen maximaal 24 uur in de politiecel te laten verblijven, als ultimum remedium: de RSJ geeft de voorkeur aan verblijf op een alternatieve locatie, zoals thuis, in een KV of in een JJI. De Minister voor Rechtsbescherming had in zijn brief van 28 juni 2019 al aangekondigd het 'nee tenzij'-principe te gaan hanteren bij verblijf in de politiecel, zonder dit te concretiseren. $^{70}$ De Minister voor Rechtsbescherming kwam vervolgens met een tweede brief op 9 juli 2020, waarin hij schrijft dat het advies van de RSJ, Minderjarigen in de politiece ${ }^{71}$ 'een groot aantal aanbevelingen bevat, waarbij de kern is dat het belang van het kind voorop staat bij alle beslismomenten en afwegingsprocessen gedurende deze fase. Hierdoor moet zo veel mogelijk voorkomen worden dat een minderjarige in een politiecel terechtkomt. Dit advies sluit aan bij het "nee tenzij"-principe waarbij het uitgangspunt is dat de jongere niet in de politiecel verblijft, tenzij dit noodzakelijk is. Met de ketenpartners wordt daarom nu gewerkt aan één aanpak met beslismomenten en motivering vanaf het moment van aanhouding tot en met inverzekeringstelling, waarbij de aanbevelingen van de RSJ worden meegenomen. De landelijke werkwijze is naar verwachting eind van dit jaar gereed. ${ }^{, 72}$

\subsubsection{Minimumleeftijd voor strafrechtelijke aansprakelijkheid}

De Minister voor Rechtsbescherming reageert in de brief van 28 juni 2019 onder meer op een advies uit 2017 van de Raad voor Strafrechtstoepassing en Jeugdbescherming, waarin de RSJ adviseert de minimumleeftijd

69. Kamerstukken // 2018/19, 28741, nr. 53, p. 8

70. Kamerstukken II 2018/19, 28741, nr. 53, p. 7.

71. Minderjarigen in de politiecel. Een advies over duur, verblijf en alternatieve locaties, Den Haag: Raad voor Strafrechtstoepassing en Jeugdbescherming, 18 december 2019

72. Kamerstukken I/ 2019/20, 29741, nr. 77, p. 7 
voor strafrechtelijke aansprakelijkheid te verhogen naar ten minste 14 jaar. ${ }^{73}$ De RSJ komt tot die conclusie op grond van drie hoofdbevindingen. ${ }^{74}$ De eerste is de aanbeveling van het $\mathrm{VN}$-Kinderrechtencomité uit (destijds nog) GC No. 10 om de minimumleeftijd op ten minste 14 jaar te stellen. ${ }^{75}$ De tweede bevinding was dat een jeugdige pas in aanmerking komt om strafrechtelijk vervolgd te worden als hij competent en capabel is om de consequenties van zijn eigen handelen te overzien. De verwijtbaarheid van het gedrag van jongeren is afhankelijk van de hersenontwikkeling en de gerelateerde ontwikkeling van functies zoals het kunnen inschatten van consequenties, aldus de RSJ. Ten slotte moet de leeftijd worden gehanteerd waarop een jeugdige snapt wat er in het strafrechtelijk proces gebeurt. Onder de 14 jaar zijn jeugdigen niet in staat om effectief een proces te begrijpen en hierin te participeren, waardoor zij mogelijk verstoken blijven van een eerlijk proces. ${ }^{76}$ Volgens de RSJ geeft dit aanleiding om deze leeftijd als minimum te nemen. ${ }^{77}$

Overigens is een eventueel nadelig effect van een verhoging naar minimaal 14 jaar, het feit dat bij ernstige strafbare feiten geen waarheidsvinding meer kan plaatsvinden met betrekking tot die feiten en dat slachtoffers geen duidelijkheid kunnen krijgen over de rol van de niet-strafbare jeugdige, anders dan het politieverhoor waaraan kinderen die niet strafbaar zijn, kunnen worden onderworpen (art. 487 lid $1 \mathrm{~Sv}$ jo. art. 56a Sv). Van den Brink en Mijnarends menen dat de waarheidsvinding nadere overdenking verdient, bijvoorbeeld de vraag hoe een 12- of 13-jarige die wordt verdacht van een ernstig strafbaar feit, maar zelf ontkent dat hij zich daaraan schuldig heeft gemaakt, zijn recht kan halen ('access to justice'). Bovendien kan het ook voor de slachtoffers belangrijk zijn dat in zaken van verdachten die jonger zijn dan de jeugdstrafrechtelijke minimumleeftijd door middel van een grondige rechterlijke procedure wordt uitgezocht wie de schuldige is van het strafbare feit. $\mathrm{Zij}$ wijzen op een procedure in Zweden, alleen gericht op waarheidsvinding, niet op veroordeling. ${ }^{78}$ Een dergelijke procedure kan dit nadelige effect ondervangen.

Minister Dekker schrijft in de brief van 28 juni 2019 dat het $\mathrm{OM}$ voor 12- en 13-jarigen al terughoudend is met het gebruik van strafrecht vanwege hun beperkte(re) vermogen om de consequenties van hun gedrag te overzien en het strafproces te volgen. De minister wil voor 12- en 13-jarigen die ernstige delicten plegen, waarbij een strafrechtelijke interventie nodig is om herhaling te voorkomen, voor die leeftijdscategorie de mogelijkheid

73. Verhoging strafrechtelijke minimumleeftijd in context. Advies over verhoging van de strafrechtelijke minimumleeftijd en het belang van goede jeugdhulp, Den Haag: Raad voor Strafrechtstoepassing en Jeugdbescherming, 20 december 2017.

74. RSJ, Verhoging strafrechtelijke minimumleeftijd in context, p. 3-4.

75. GC No. 10, par. 32-33.

76. RSJ, Verhoging strafrechtelijke minimumleeftijd in context, p. 13

77. RSJ, Verhoging strafrechtelijke minimumleeftijd in context, p. 5.

78. Y.N. van den Brink \& E.M. Mijnarends, 'General Comment No. 24 nieuw elan voor het jeugdstrafrecht. Over leeftijdsgrenzen, 'diversion' en de bredere implicaties voor het jeugdstrafrecht', Boom Strafblad 2020, 1, p. 12 van strafrechtelijk ingrijpen behouden. Hij stelt daarbij ook dat de leeftijdgrens van 12 jaar in overeenstemming is met het IVRK. ${ }^{79}$ Strikt genomen was dat op het moment van schrijven van de brief het geval; toen was GC No. 24 nog niet verschenen en stelde GC No. 10 de leeftijd van 12 jaar als absolute ondergrens van de minimumleeftijd, maar werd ook al 14 of 16 jaar genoemd als gewenste leeftijd. Inmiddels is GC No. 24 gepubliceerd en zou de minister zijn besluit moeten heroverwegen, nu het VN-Kinderrechtencomité een leeftijdgrens van 14 jaar stelt, waarbij 15 of zelfs 16 wenselijker is. Vasthouden aan 12 jaar druist in tegen ontwikkelingspsychologische en internationaalrechtelijke argumenten.

\subsection{Reprimande}

Per 1 oktober 2020 is een landelijke pilot reprimande gestart, voor de duur van een jaar. De pilot is bedoeld voor de minderjarige first offender die een licht misdrijf pleegt. Indien minderjarigen verdacht worden van een misdrijf, zijn zij verplicht gebruik te maken van consultatiebijstand en verhoorbijstand (art. 498 lid 2 jo. art. 28a Sv, zie par. 2). Dit heeft tot gevolg dat de verdachte geruime tijd van zijn vrijheid kan worden beroofd, ook als hij verdacht wordt van een licht feit en in aanmerking zou kunnen komen voor een reprimande. Een reprimande houdt in dat feit en dader (als verdachte) worden geregistreerd door de politie, en dat er een mondelinge waarschuwing door de politie wordt gegeven aan verdachte. Ouders worden in kennis gesteld en eventuele schade wordt vergoed. Er wordt geen inhoudelijke sanctie opgelegd. Omstandigheden die een rol kunnen spelen bij de beslissing om te volstaan met een reprimande zijn bijvoorbeeld: zeer jeugdige leeftijd, geringe gevolgen en/of aard van het feit, optreden van ouders of anderen, zoals school, of het reeds vergoed zijn van toegebrachte schade. ${ }^{80}$ Politie, OM en Halt hebben een werkwijze ontwikkeld waarbij deze verdachten na aanhouding niet worden overgebracht naar het politiebureau, maar ter plaatse telefonisch worden voorgeleid aan de hulpofficier van justitie (hOvJ). Als de minderjarige verdachte volgens de hOvJ in aanmerking komt voor een reprimande, geeft de hOvJ dit bij de verdachte aan en wordt de verdachte in vrijheid gesteld. Tijdens deze telefonische voorgeleiding wordt de verdachte niet inhoudelijk gehoord, maar worden er alleen procesvragen gesteld om te achterhalen of de verdachte begrijpt waarom hij is aangehouden en of de aanhouding rechtmatig heeft plaatsgevonden. Deze procedure heeft tot voordeel dat verdere vrijheidsbeneming op het politiebureau in afwachting van een raadsman niet noodzakelijk is en kort daarna een reprimandegesprek kan plaatsvinden. ${ }^{81}$ De politie voert het reprimandegesprek en legt dit vast in de Basisvoorziening Handhaving (BVH) ${ }^{82}$ Zoals blijkt uit paragraaf 4.1

79. Kamerstukken // 2018/19, 28741, nr. 53, p. 8-9

80. Richtlijn en kader voor strafvordering jeugd en adolescenten, inclusief strafmaten Halt, 1 juni 2018, par. 4.1

81. Bron: Rianne de Back, officier van justitie bij het parket Amsterdam.

82. https://www.politie.nl/nieuws/2020/oktober/1/00-pilot-reprimandeminderjarige-verdachten-van-start.html 
meent het VN-Kinderrechtencomité dat juridische bijstand of andere passende bijstand noodzakelijk is bij alternatieve afdoeningen. ${ }^{83}$ Hoewel het te verwachten valt dat vrijheidsbeneming van minderjarigen door de reprimande beperkt wordt, is het nog maar de vraag of ouders de noodzakelijke appropriate assistance kunnen bieden. De pilot zal na een jaar worden geëvalueerd door het WODC. Hopelijk wordt ook dit aspect in de evaluatie betrokken.

\section{Toekomstige ontwikkelingen}

\subsection{Wetsvoorstel harmonisering rechtspositie jeugdigen in geslotenheid}

Op 2 juli 2020 boden de Ministeries van Justitie en Veiligheid en van Volksgezondheid, Welzijn en Sport het wetsvoorstel Wet rechtspositie gesloten jeugdinstellingen ter consultatie aan. ${ }^{84}$ In de eerste plaats wordt met dit wetsvoorstel beoogd de rechtspositie van jeugdigen in geslotenheid te verbeteren. In de tweede plaats heeft het wetsvoorstel tot doel de rechtspositie van deze jeugdigen zo veel mogelijk te harmoniseren. Tot slot ondersteunt dit wetsvoorstel de ontwikkeling naar meer kleinschaligheid bij het gesloten plaatsen van jeugdigen.

De basis van het wetsvoorstel wordt gevormd door drie te onderscheiden regimes van gesloten plaatsingen voor jeugdigen: 1. het beperkt gesloten regime (Kleinschalige Voorzieningen), 2. het gesloten regime (instellingen voor jeugdzorgplus), en 3 . het hoog beveiligd gesloten regime (justitiële jeugdinrichtingen). Oplopend van het beperkt gesloten regime naar het hoog beveiligd gesloten regime is er sprake van verschillende beveiligingsniveaus die gepaard gaan met meer en ingrijpendere mogelijkheden met betrekking tot het toepassen van vrijheidsbeperkende maatregelen. In het hoog beveiligd gesloten regime kunnen tot slot disciplinaire straffen worden opgelegd. Jeugdigen met een strafrechtelijke titel kunnen in het beperkt gesloten regime en het hoog beveiligd gesloten regime worden geplaatst. Jeugdigen met een civielrechtelijke titel kunnen in het beperkt gesloten regime en het gesloten regime worden geplaatst. ${ }^{85}$ Zowel Defence for Children Nederland ${ }^{86}$ als de Raad voor Strafrechtstoepassing en Jeugdbescherming (RSJ) hebben kritische adviezen geschreven. De strekking van beide adviezen is dat het wetsvoorstel op bepaalde punten een verslechtering van de rechtspositie van jeugdigen in geslotenheid betekent. De RSJ concludeert dat het wetsvoorstel weliswaar een harmonisatie beoogt, maar dat die niet wordt bereikt vanwege het feit dat de Beginselenwet Justitiële Jeugdinrichtingen (Bjj) naast deze wet blijft bestaan en de rechtspositie van de jongeren in de jeugd-ggz niet is geintegreerd in het wetsvoorstel. De RSJ adviseert om hoofdstuk 6 van de

83. GC No. 24, par. 72

84. Zie https://www.internetconsultatie.nl/rechtspositiegeslotenjeugdhulp.

85. MvT, wetsvoorstel Wet rechtspositie gesloten jeugdinstellingen, p. 15

86. Reactie Defence for Children, 14 september 2020, p. 33, https:// www.internetconsultatie. $\mathrm{nl} /$ rechtspositiegeslotenjeugdhulp.
Jeugdwet en de $\mathrm{Bjj}$ te integreren tot één overkoepelende wet, waarbij ook aandacht dient te worden besteed aan de rechtspositie van jeugdigen die gesloten zijn geplaatst in de jeugd-ggz. ${ }^{87}$

\subsection{Wetsvoorstel tot vaststelling van het nieuwe Wetboek van Strafvordering}

Op 30 juli 2020 werden, onaangekondigd, de ambtelijke versies van het Wetsvoorstel tot vaststelling van het nieuwe Wetboek van Strafvordering ${ }^{88}$ en de memorie van toelichting gepubliceerd. ${ }^{89}$ De consultatieversies van Boek 3 tot en met 6 waren reeds op 5 december 2017 verschenen en daarna werd het stil. Boek 1 en 2 waren op 7 februari 2017 ter consultatie aangeboden. Boek 1 heeft de titel: 'Strafvordering in het algemeen', Boek 2 betreft het opsporingsonderzoek, Boek 3 betreft beslissingen over vervolging, Boek 4 betreft de berechting, Boek 5 bevat bepalingen over rechtsmiddelen en Boek 6 bevat bijzondere regelingen, onder andere met betrekking tot jeugdige verdachten. Deze paragraaf beschrijft de relevante/opvallende bepalingen uit de voorgestelde boeken.

\subsubsection{Boek 2 Het opsporingsonderzoek}

Voor alle verdachten geldt het volgende. In voorlopige hechteniszaken wordt de 'negentigdagentermijn' doorbroken. Dit betekent dat de termijn gedurende welke het bevel gevangenhouding van kracht is steeds door de raadkamer wordt getoetst en kan worden verlengd met periodes die telkens niet langer zijn dan drie maanden (art. 2.5.45). Vanaf drie maanden gevangenhouding is de behandeling door de raadkamer van de vordering tot verlenging openbaar (art. 2.5.20). Zo spoedig mogelijk, maar uiterlijk drie maanden nadat de gevangenhouding van de verdachte is bevolen, informeert de officier van justitie, indien hij nog geen procesinleiding kan indienen, de verdachte en de rechter-commissaris over de stand van zaken in het opsporingsonderzoek. Hij geeft daarbij een (voorlopige) tenlastelegging en een aanduiding van het moment waarop de zaak naar verwachting bij de rechter zal worden aangebracht. Daarnaast zorgt de officier van justitie ervoor dat de verdachte kan kennisnemen van de beschikbare processtukken (art. 2.10.66). Het 'stand-van-zakenbericht' beoogt de verdachte beter in staat te stellen zijn verdediging voor te bereiden, bijvoorbeeld door onderzoekswensen kenbaar te maken aan de rechter-commissaris. Zo wordt ook de rechter-commissaris beter in staat gesteld de voortgang van het opsporingsonderzoek te bewaken en die waar nodig door de inzet van zijn bevoegdheden te bevorderen. ${ }^{90}$

87. Advies Wetsvoorstel Rechtspositie Gesloten jeugdinrichtingen, Den Haag: Raad voor Strafrechtstoepassing en Jeugdbescherming, 15 september 2020, p. 25

88. https://www.rijksoverheid.nl/documenten/publicaties/2020/07/30/ ambtelijke-versie-juli-2020-wetsvoorstel-wetboek-van-strafvordering.

89. https://www.rijksoverheid.nl/documenten/publicaties/2020/07/30/ ambtelijke-versie-juli-2020-memorie-van-toelichting-wetboek-vanstrafvordering.

90. MvT, p. 299. 
Artikel 2.5.31 verplicht de rechter om na te gaan of de tenuitvoerlegging van de door hem bevolen voorlopige hechtenis onmiddellijk of na een bepaald tijdsverloop kan worden geschorst. De verplichting voor de rechter om schorsing van de voorlopige hechtenis te overwegen, kent het huidige wetboek al in de bepalingen over strafvordering in zaken betreffende jeugdige personen (art. $493 \mathrm{~Sv}$ ). De verplichting kriigt nu een algemeen geldend karakter, zodat zij niet in Boek 6 in de bepalingen over jeugdige verdachten behoeft terug te keren. ${ }^{91}$

\subsubsection{Boek 6 Bijzondere regelingen}

Verdachten onder de 12 jaar krijgen recht op een toegevoegd raadsman. In artikel 6.1 .3 lid 2 wordt namelijk artikel 6.15 lid 2 van toepassing verklaard, dat inhoudt dat indien de verdachte is aangehouden, de officier van justitie of de hulpofficier van justitie die bij de voorgeleiding beveelt dat de verdachte wordt opgehouden voor onderzoek, het bestuur van de Raad voor Rechtsbijstand direct van zijn aanhouding in kennis stelt, opdat het bestuur een raadsman aanwijst. Deze kennisgeving kan achterwege blijven indien de verdachte een raadsman heeft gekozen en deze of een vervangende raadsman tijdig beschikbaar zal zijn. Dit is een heel belangrijk artikel, aangezien ook minderjarigen onder de 12 jaar blootgesteld worden aan dwangmiddelen. Artikel 6.1.3 lid 2 schrijft voor dat de Raad voor de Kinderbescherming op de hoogte wordt gesteld van ophouden voor verhoor van verdachte onder de 12 jaar.

Het recht op een toegevoegd raadsman wordt uitgebreid. Wanneer het een zaak betreft waarbij vervangende jeugddetentie aan de orde is, wordt een raadsman toegevoegd (art. 6.1.5 lid 5). Dit artikel lijkt het advies van RSJ van deze strekking te volgen, gedaan in het kader van de implementatie van Richtlijn 2016/800/ EU. ${ }^{92}$

De mogelijkheid tot advies door de Raad voor de Kinderbescherming wordt uitgebreid. In artikel 6.1.9 lid 3 wordt het mogelijk gemaakt voor de officier van justitie om inlichtingen in te winnen bij de Raad in het kader van een strafbeschikking en een kantongerechtprocedure, bijvoorbeeld bij een leerplichtzaak.

Het bevel tot gevangenneming of gevangenhouding is van kracht gedurende een door de rechtbank te bepalen termijn van ten hoogste een maand (art. 6.1.11 lid 2). Indien een vordering tot een PIJ wordt aangekondigd door de officier van justitie kan het bevel tot voorlopige hechtenis wel met een termijn van drie maanden worden gevorderd en toegewezen. $\mathrm{Na}$ eindvonnis is het bevel voorlopige hechtenis één in plaats van twee maanden van kracht, behalve als een PIJ-maatregel wordt opgelegd. Artikel 6.1 .11 lid 6 bepaalt dat zittingen met betrekking tot de voorlopige hechtenis altijd in beslotenheid plaatsvinden.

Daarnaast gaat de alternatieve afdoening Halt (Het Alternatief) 'pedagogisch programma' heten en wordt

91. MvT, p. 313.

92. Advies EU Richtliin Jeugd, Den Haag: Raad voor Strafrechtstoepassing en Jeugdbescherming, 31 januari 2018. deze verplaatst naar het Wetboek van Strafvordering in het voorgestelde artikel 6.1.13.

Een voorstel dat met open armen zal worden ontvangen is het voorgestelde artikel 6.1.22. In dit artikel wordt artikel 6.1.11 lid 8 van toepassing verklaard. Dit houdt in dat de rechter in alle stadia van het proces de volwassen verdachte tot 23 jaar in een JJI mag plaatsen. De rechter is dan dus niet meer afhankelijk van het voornemen van de officier van justitie om het minderjarigenstrafrecht toe te passen op de meerderjarige verdachte.

De kantonrechter kan ex artikel 6.1.34 de oproeping van een ouder bevelen. Volgens het huidige artikel 496a Sv kan dat niet, nu dit alleen bij misdrijf mogelijk is. De oproeping kan dus dan ook in leerplichtzaken.

Een andere interessante bepaling betreft de ouders van de minderjarige verdachte. De ouders van de minderjarige die 12 of 13 jaar was ten tijde van het gepleegde feit, die geconfronteerd worden met een vordering benadeelde partij, kunnen hoger beroep dan wel cassatie instellen tegen toewijzing van de vordering voor een bedrag boven de $€ 1.750$ (art. 6.1.40).

\section{Conclusie}

De afgelopen achttien maanden is er veel gebeurd met betrekking tot het jeugdstraf(proces)recht in het Koninkrijk der Nederlanden en daarbuiten - en er staan ons nog veel wijzigingen te wachten. Deze uitgebreide kroniek is daar het uitvloeisel van en illustreert meteen ook de eclectische ard van het (internationale) jeugdstraf(proces)recht. Het IVRK ziet de toepassing van het jeugdstrafrecht als een ultimum remedium. Maar als het dan toch toegepast moet worden, moet het ten dienste staan van de re-integratie van de jeugdige verdachte. Daarnaast moet sprake zijn van maatwerk, van alternatieven voor strafrechtelijke afdoening, van rechtswaarborgen zoals een eerlijk proces en recht op rechtsbijstand. Als wij de ontwikkelingen van de afgelopen periode tegen het licht houden van het IVRK, komt er veelal niet een fraai beeld naar voren: de Wet USB, de Spoedreparatiewet USB, het behoud van de leeftijd van 12 jaar voor strafrechtelijke aansprakelijkheid, sluiting van JJI's in het noorden en zuiden van ons land, het treurige beeld van 410.000 kinderen die jaarlijks met strafrechtelijke vrijheidsberoving te maken krijgen en een minister die de wet niet annast met betrekking tot DNA-afname voor taakstraffen vanaf 40 uur, stemmen somber. Er zijn echter ook lichtpuntjes: een versterking van de rechtspositie van de minderjarige aangehouden verdachte, de minister die de maximale jeugddetentie niet wenst te verhogen, een omvangrijk en gezaghebbend General Comment No. 24 van het VN-Kinderrechtencomité, een toezegging van de minister om het nee-tenzij-principe toe te passen in relatie tot kinderen in de politiecel, de komst van Kleinschalige Voorzieningen, de landelijke reprimandepilot die vrijheidsbeneming van minderjarigen moet verminderen, de 
komst van het jeugdstrafrecht in Caribisch Nederland en een nieuw Wetboek van Strafvordering waardoor kinderen onder de 12 jaar recht krijgen op een toegevoegd raadsman en de rechter eindelijk kan beslissen of hij een volwassen verdachte tot 23 jaar in een JJI wil plaatsen.

De balans kan dus worden opgemaakt: het jeugdstrafrecht is in beweging, soms good, soms bad, maar afgelopen jaar ook ronduit ugly. 